DOI: https://doi.org/10.32839/2304-5809/2020-12-88-57

уДК 159.923

Салюк М.А., Тарасюк Х.O.

Дніпровський національний університет імені Олеся Гончара

\title{
РОЛЬ ІМПЛІЦИТНИХ ТЕОРІЙ У ЗАБЕЗПЕЧЕННІ ПСИХІЧНОЇ САМОРЕГУЛЯЦІЇ ДІЯЛЬНОСТІ ТА АДАПТАЦІЙНОГО ПОТЕНЦІАЛУ ОСОБИСТОСТІ
}

Анотація. У статті представлено аналіз змісту понять «адаптаційний потенціал особистості», «психічна саморегуляція» «імпліцитні теорії», теоретично обгрунтовано можливість розгляду особливостей імпліцитних уявлень людини про інтелект та особистість у якості важливих предикторів забезпечення психічної саморегуляції та адаптаційного потенціалу особистості. Теоретичний аналіз наукових джерел дозволив зробити припущення про те, що прийняття інкрементальних імпліцитних теорій сприяе позитивному мисленню людини та їі успішному фрункціонуванню в соціумі. Наведено результати проведеного емпіричного дослідження для з'ясування характеру взаємозв'язків між імпліцитними уявленнями (теоріями) людей та особливостями їх базисних життевих переконань, самоорганізації діяльності, фрормально-динамічних і якісних ознак адаптивності, показників психологічного благополуччя особистості. Результати підтверджують гіпотезу стосовно того, що схильність до інкрементальних уявлень про інтелект і особистість можуть розглядатися в якості важливих фракторів (предикторів) підвищення рівня психічної саморегуляції та адаптаційного потенціалу особистості.

Ключові слова: імпліцитні теорї особистості та інтелекту, інкрементальна імпліцитна теорія, психічна саморегуляція, адаптаційний потенціал, психологічне благополуччя.

Saliuk Maryna, Tarasiuk Khrystyna Oles Honchar Dnipro National University

\section{THE ROLE OF IMPLICIT THEORIES IN THE PROVIDING MENTAL SELF-REGULATION OF ACTIVITY AND ADAPTATION POTENTIAL OF PERSONALITY}

Summary. The problem of implicit theory and personal adaptive potential has been researched in the works by C. Dweck, K. Fomenko, D. Leontiev, A. Maklakov, O. Sannikova \& O. Kuznietsova et al. This research is aimed to investigate the interrelation between incremental implicit theories of intelligence and personality and psychological adaptive potential of personality. Applied psychodiagnostic techniques: "Structural Composition of Personal Adaptability" (Sannikova, Kuznetsova, 2017); C. Dweck's implicit theories of intelligence and personality questionnaire (adapted by T.V. Kornilova), the Scale of basic beliefs (R. Yanov-Bulman, adapted by M.A. Padun and A.V. Kotelnikova); the questionnaire of self-organization of activity (adapted by E.Y. Mandrykova); the Ryff Scales of Psychological Well-being (adapted by T.D. Shevelenkova \& T.P. Fesenko). The sample included 80 testers, aged from 17 to 60 . The results of the empirical research were processed with the help of r-Pearson criterion for the correlation detection and multiple regression analysis. The results of the empirical research finds out the nature of the relationship between the implicit ideas (theories) of intelligence and personality of the subjects and their adaptive potential. The results confirm the hypothesis that acceptance of the theories of "enriched" intelligence and personality is accompanied by more pronounced indicators of socio-psychological adaptation. In the practical application of the results will be efficient correction of individual's expectations systems regarding to the positive results of their activity and training internal cognitive characteristics, which will cause higher level of individual's self-efficacy and psychological well-being. This will increase adaptive capacity in difficult life circumstances and will improve significantly the process of counseling. Keywords: implicit theory of personality, implicit theory of intelligence, entity implicit theory, mental selfregulation of activity, psychological adaptive potential, psychological well-being.

Постановка проблеми. Для успішного фоннкціонування та розвитку в постійно змінюваних умовах людина змушена адаптуватися та ефрективно регулювати власну життедіяльність. Отже не викликає подиву підвищена увага сучасних дослідників до проблем психічної саморегулящії та адаптащійного потенціалу особистості. Неабиякий вплив на життедіяльність особистості, зокрема на її сприйняття та розуміння себе й оточуючих, на взаємовідносини 3 іншими, здійснюють імпліцитні теорії (імпліцитні уявлення) - суб'єктивні пояснювальні схеми, основна мета яких полягає у побудові цілісної картини світу. Від того, як ці схеми сформовані залежить емоційний стан людини, її відношення до подій, що відбуваються в житті, до оточуючих тощо.

Аналіз останніх досліджень і публікацій. Адаптаційний потенціал - це системна властивість особистості, що обумовлюе характер про- тікання адаптації до змін умов навколишнього середовища, а також визначає межі адаптивних можливостей особистості. На формування адаптаційного потенціалу впливає ціла низка психологічних особливостей особистості людини. Згідно 3 концепцією адаптаційного потенціалу особистості, яку запропонував визнаний фрахівець в щій галузі досліджень А.Г. Маклаков, можна виділити в структурі даного феномену такі характеристики: нервово-психічну стійкість, рівень розвитку якої забезпечує толерантність до стресу; самооцінку особистості, що є ядром саморегуляції і визначає ступінь адекватності сприйняття умов діяльності та своїх можливостей; відчуття соціальної підтримки, що обумовлюе почуття власної значущості для оточуючих; рівень конфрліктності особистості; досвід соціального спілкування [5]. Даний підхід є актуальним та важливим в руслі психологічних досліджень феномену адаптації, 
адже саме він підкреслює вагоме значення психологічних фракторів в процесі гармонійного пристосування до впливів навколишнього середовища.

Варто відзначити дослідження Ф.Б. Березіна щодо феномену адаптації. На його думку, адаптація - це процес не лише збереження фрізіологічного, але і психічного гомеостазу, тобто оптимальна постійна взаємодія людини 3 навколишнім середовищем і установка найбільш ефрективної відповідності між фрізіологічними і психологічними фракторами в процесі формування відносно стабільних психофрізіологічних відношень [1].

Подальші дослідження розширили уявлення про феномен адаптаційного потенціалу і зумовили виникнення споріднених понять. Так, Д.О. Леонтьев [4] визначає "особистісний потенціал» як базову індивідуальну характеристику, як стрижень особистості, який $є$ інтегральною характеристикою рівня особистісної зрілості, відображає міру подолання особистістю заданих обставин, в кінцевому рахунку, подолання особистістю самої себе, а також міру прикладених нею зусиль по роботі над собою і над обставинами свого життя.

С.Т. Посохова припускає, що до адаптаційного потенціалу закладена латентність адаптаційних здібностей, своєчасність й вектор реалізації яких залежить від активності особистості. Особистісний адаптаційний потенціал включае біопластичний, біографрічний, психічний та особистісно-регуляторний компоненти [6].

Українські дослідниці О.П. Саннікова та О.В. Кузнецова описали комплекс формальнодинамічних i якісних характеристик адаптивності особистості та виділили три основних компоненти психічної адаптивності (когнітивний, емоційно-мотиваційний, поведінковий) [7].

Володіння навичками довільної саморегуляції свідчить про можливості й уміння людини усвідомлювати свої цілі, будувати систему дій, спрямованих на досягнення цих цілей, моделювати умови середовища для оптимального вирішення проблем, контролювати, коригувати програму дій в залежності від ситуацій, що складаються. Формування єдиної для безлічі різних діяльностей системи саморегулящії дозволяе підготувати людину в майбутньому до змін поведінки у ситуаціях, що схильні до трансформації, адаптації до постійно мінливих умов діяльності. При наявності і вдосконаленні у людини системи саморегулящії виникає тенденція до усвідомленого прояву і розуміння себе як суб'єкта діяльності, в результаті чого зменшуеться конфліктність, підвищуеться впевненість в собі, поліпшується самопочуття.

В руслі дослідження даної проблематики праџюе сучасний дослідник П.Р. Галузо. Так, у свойй роботі він доводить, що існуе взаємозв'язок між загальним рівнем особистісної усвідомленої регулящії навчальної діяльності та імпліцитними теоріями «нарощуваного інтелекту» [2]. Цей взаємозв'язок $€$ підтвердженням складної структурної та змістовної організації саморегулящії суб'єкта навчальної діяльності, що включає в себе як регуляторні процеси свідомості, так і життеві уявлення про можливості розвитку інтелекту і продесіоналізащії в процесі навчання у вузі. Прийняття імпліцитної теорії "нарощуваного інтелекту» впливає на рівень фрункціональної дієвості в індивідуальних системах особистісної усвідомленої регуляції навчальної діяль- ності, розуміння життевого сенсу, пілепокладання, моделювання та контролю навчальної діяльності.

Ще одна сучасна дослідниця Н.С. Захарова, наголошуе, що основою для розкриття особливостей адаптації людини є система суб'єктно-особистісного потенщіалу, що включає чотири складові: саморегулящію, імпліцитні теорї особистості та інтелекту, локус контролю та самоактуалізацію [3].

Існуючі у кожної людини переконання (імпліцитні теорії) щодо власної особистості та інтелекту можуть здійснювати неабиякий вплив на загальний процес становлення та розвитку особистості. Наприклад, представники інкрементальної імпліщитної теорії особистості вважають, що в процесі спілкування з іншими людина розвивається і є суб'єктом свого особистісного розвитку. Натомість, з позиції стабільної імпліцитної теорії, особистість є незмінною впродовж всього життя [9]. Дещо подібними є уявлення особистості про власний інтелект. Зокрема ті, хто вважають власні інтелектуальні здібності стабільними та незмінними, схильні до постановки результативних цілей, тобто, для них важливими є лише сам результат, а також позитивна оцінка своїх умінь з боку оточуючих. Натомість ті особистості, які припускають, що ïx здібності піддаються покращенню і тренуванню, схильні ставити перед собою пізнавальні цілі, тобто вони прагнуть покращити свою компетентність.

Поняття імпліцитних теорій було запропоновано в психології американськими дослідниками Дж. Брунером і Р. Тагіурі [8]. Спочатку об'єктом досліджень науковців стали імпліцитні теорії особистості як сукупність звичайних знань про психологію людини. Базою для їх вивчення стала теорія особистісних конструктів Дж. Келлі. За своєю сутністю імпліцитні теорії виконують регулятивну та прогностичну фрункції, лежать в основі стереотипізації, каузальної атрибуції та інших френоменів міжособистісного сприймання. Таким чином, імпліцитні уявлення розглядаються як важливе підгірунтя картини світу людини та значно впливають на їі самосвідомість.

Одним 3 найбільш відомих підходів до проблеми імпліцитних теорій є соціально-когнітивна теорія К.С. Двек. В своїх роботах американська дослідниця аналізуе чому люди досягають успіху i як можна цьому сприяти. На думку вченої, головну роль тут відіграють переконання та уявлення людини. Наприклад, уявлення суб'єкта про власний інтелект має важливе значення для мотивації, спрямованої на досягнення. К.С. Двек підкреслюе, що переконання мають значення, ïх можна змінити, а разом із ними і особистість. Переконання людини включають їі ментальні репрезентації про сутність і фрункціонування Я, взаемостосунки особистості та її світ [9].

Виділення не вирішених раніше частин загальної проблеми. Отже, на основі теоретичного аналізу наукової літератури ми можемо стверджувати, що імпліцитні теорії виступають важливою передумовою забезпечення ефективної психічної саморегуляції життедіяльності особистості та можуть розглядатися у контексті розвитку особистісного адаптаційного потенщіалу. Інкрементальні імпліцитні уявлення сприяють підвищенню рівня саморегуляції діяльності та відіграють важливу роль у зумовленні здатності людини адаптуватися в мінливих умовах життедіяльнос- 
ті. Не зважаючи на певні наукові напрацювання зарубіжних та вітчизняних дослідників 3 приводу проблеми взаємозв'язків імпліцитних уявлень людини 3 успішністю саморегуляції діяльності та адаптивністю, до цьог часу немає чіткої відповіді на питання стосовно ролі суб'єктивних переконань про особистість та інтелект у формуванні адаптаційного потенціалу особистості.

Метою даної статті $є$ виклад результатів емпіричного дослідження, яке проводилось для перевірки припущення про те, що імпліщитні теорії можуть виступати в якості важливих предикторів ефрективності психічної саморегуляції та адаптаційного потенціалу особистості.

Виклад основного матеріалу. В емпіричному дослідженні взяло участь 80 осіб. Вибірку склали мешканці Львівської, Київської, Дніпропетровської та Запорізької областей. Вік досліджуваних - від 17 до 60 років.

Психодіагностичні методики дослідження: опитувальник імпліцитних теорій і цілей навчання К. Двек (в модифрікації Т.В. Корнілової та С.Д. Смірнова); Шкала базисних переконань (Р. Янов-Бульмана, в адаптащії М.А. Падун та А.В. Котельникової); Опитувальник самоорганізації діяльності (адаптований Є.Ю. Мандриковою); Тест-опитувальник діагностики формально-динамічних і якісних ознак адаптивності (О.П. Саннікова, О.В. Кузнецова, 2005); Шкала позитивного афекту і негативного афректу (в адаптації Є.М. Осина); Шкала психологічного благополуччя К. Pidpd (в адаптації Т.Д. Шевеленкової та Т.П. Фесенко).

Обробка результатів емпіричного дослідження була проведена за допомогою коефіцієнту кореляції r-Пірсона; процедури множинного регресійного аналізу для прогнозування загального показника адаптивності особистості на основі показників імпліцитних теорій.

Результати розрахунків коефіцієнтів кореляції між рівнем схильності досліджуваних до пев- ного типу імпліцитних теорій (IT) та самоорганізацією діяльності (наполегливість, орієнтація на теперішне, планомірність, самоорганізація, фріксація, цілеспрямованість, загальний показник самоорганізащіi) представлені в таблиці 1.

Виходячи 3 отриманих результатів, можемо зробити висновок, що загальний показник самоорганізації має статистично значущий позитивний зв'язок зі схильністю до прийняття імпліцитної теорії «нарощуваного» інтелекту $(\mathrm{r}=0,255)$.

В ході дослідження ми також перевірили наявність значущих кореляційних зв'язків між показниками імпліцитних теорій інтелекту й особистості та показниками базисних переконань особистості (таблиця 2).

Прийняття імпліцитної теорії «збагачуваної» особистості має позитивний кореляційний зв'язок iз показником доброзичливості світу $(r=0,230)$. Щодо показнику прийняття імпліцитної теорії «нарощуваного» інтелекту, тут виявлені позитивні зв'язки з такими компонентами базисних переконань, як удача $(r=0,249)$ та переконання про контроль $(\mathrm{r}=0,223)$.

Звернемося до результатів встановлення кореляційних зв'язків між показниками прийняття імпліцитних теорій інтелекту й особистості та показниками формально-динамічних і якісних ознак адаптивності (таблиця 3).

Виходячи 3 отриманих результатів, можна зазначити, що показники імпліцитних теорій «нарощуваного» інтелекту $(\mathrm{r}=0,376)$ та «збагачуваної» особистості $(r=0,293)$ мають позитивні статистично значущі кореляційні зв'язки із загальним показником адаптивності (ЗПА). Також схильність до інкрементальних імпліцитних теорій позитивно пов'язана 3 такими компонентами адаптивності особистості: широта охоплення сигналів сощіуму (ШОСС), легкість розпізнавання та ієрархізації сигналів соціума (ЛІСС), точність орієнтації в соціальних очікуваннях (ТОСО), стійкість емоцій-

Характер кореляційних зв'язків між показниками імпліцитних теорій

Таблиця 1 інтелекту й особистості та самоорганізаціею діяльності

\begin{tabular}{|l|c|c|}
\hline \multicolumn{1}{|c|}{$\begin{array}{c}\text { Показники самоорганізації } \\
\text { діяльності }\end{array}$} & IT «нарощуваного» інтелекту & IT «збагачуваної» особистості \\
\hline Наполегливість & 0,160 & 0,172 \\
\hline Оріентація на теперішне & 0,054 & 0,118 \\
\hline Планомірність & 0,190 & 0,123 \\
\hline Самоорганізація & 0,064 & 0,083 \\
\hline Фіксація & 0,117 & $-0,087$ \\
\hline Цілеспрямованість & 0,154 & 0,032 \\
\hline Загальник показник самоорганізації & $\mathbf{0 , 2 5 5 *}$ & 0,137 \\
\hline
\end{tabular}

Примітка: * - статистично значущі зв'язки на рівні $\mathrm{p} \leq 0,05$.

Характер кореляційних зв'язків між показниками імпліцитних теорій

Таблиця 2 інтелекту й особистості та показниками базисних переконань особистості

\begin{tabular}{|l|c|c|}
\hline \multicolumn{1}{|c|}{ Показники } & IT «нарощуваного» інтелекту & IT «збагачуваної» особистості \\
\hline Доброзичливість світу & 0,122 & $\mathbf{0 , 2 3 0 *}$ \\
\hline Справедливість & 0,055 & 0,063 \\
\hline Образ «Я» & 0,141 & 0,133 \\
\hline Удача & $\mathbf{0 , 2 4 9 *}$ & 0,102 \\
\hline Переконання про контроль & $\mathbf{0 , 2 2 3 *}$ & 0,115 \\
\hline
\end{tabular}

Примітка: * - статистично значущі зв'язки на рівні $\mathrm{p} \leq 0,05$. 
Характер кореляційних зв'язків між показниками імпліцитних теорій та формально-динамічних і якісних ознак адаптивності

\begin{tabular}{|c|c|c|}
\hline Показники адаптивності & IT «нарощуваного» інтелекту & IT «збагачуваної» особистості \\
\hline ШОСС & $0,320 * *$ & 0,147 \\
\hline JICC & $0,323 * *$ & $0,245 *$ \\
\hline TOCO & $0,311^{* * *}$ & $0,312^{* * *}$ \\
\hline СЕП & 0,287 *** & 0,194 \\
\hline$\Gamma 3$ & $0,284 *$ & $0,234 *$ \\
\hline ДПН & 0,219 & $0,275^{*}$ \\
\hline ГДМ & $0,245 *$ & 0,171 \\
\hline C33 & 0,124 & 0,145 \\
\hline ЗПА & $0,376^{* * *}$ & $0,293 * * *$ \\
\hline
\end{tabular}

Примітка: * - статистично значущі зв'язки на рівні $\mathrm{p} \leq 0,05$

** - статистично значущі зв'язки на рівні $\mathrm{p} \leq 0,01$

ного переживання (СЕП), готовність змінюватись (ГЗ), готовність до здійснення конструктивних дій, спрямованих на досягнення мети (ГДМ); готовність до здійснення конструктивних дій, спрямованих на подолання невдач (ДПН).

Звернемося до встановлення кореляційних зв'язків між показниками імпліцитних теорій та показниками психологічного благополуччя i його складовими компонентами, а також показниками прояву позитивних та негативних емоцій в житті людини (таблиця 4).

Виходячи з отриманих результатів можна зазначити, що імпліцитна теорія «збагачуваної» особистості мае статистично значущий позитивний кореляційний зв'язок із загальним показником психологічного благополуччя, а також такими його складовими компонентами як позитивні відношення, автономія, самоприйняття. Кореляційний зв'язок між показниками імпліцитної теорії «нарощуваного» інтелекту та загальним показником психологічного благополуччя не досягае статистичної значущості, однак, були встановлені позитивні корелящійні зв'язки з такими компонентами благополуччя, як позитивні відношення, цілі в житті, самоприйняття.

З огляду на отримані позитивні статистично значущі кореляційні зв'язки вважаємо доцільним побудову кореляційно-регресійної моделі для оцінки можливостей прогнозування загальних показників адаптивності особистості на основі її показників схильності до імпліщитних теорій «нарощуваного» інтелекту і «збагачувальної» особистості. Статистична обробка результатів було реалізована за допомогою лінійного множинного регресійного аналізу.

Незалежними змінними (предикторами) було обрано показники імпліцитних теорій «нарощуваного» інтелекту і «збагачувальної» особистості за методикою К. Двек. Залежною змінною є загальний показник адаптивності особистості.

За результатами статистичної обробки було побудовано однофракторну кореляційно-регресійну модель адаптивності особистості:

Загальний показник адаптивності особистості $=22,64+0,38 *$ прийняття теорї̈ "нарощуваного" інтелекту

Результати регресійної статистики наведено в табл. 5, загальна характеристика побудованої кореляційно-регресійної моделі представлена в табл. 6.

Величина коефріпіенту множинної кореляції для побудованої моделі стресостійкості дорівнюе 0,376, виділений фрактор (прийняття теорії «нарощуваного» інтелекту) корелюе позитивно. Стандартний коефіцієнт регресії відображає відносний ступінь впливу фрактору - предиктору: для змінної «Прийняття теорії «нарощуваного» інтелекту» $\mathrm{p}=0,376$.

Значення R-квадрату (коефіцієнту детермінації) дорівнюе 0,141 . Це значить, що частка дисперсії результату Y (загального показника адаптивності), пояснена регресією, складає 14,1\%.

Таблиця 4

Характер кореляційних зв'язків між показниками імпліцитних теорій інтелекту й особистості та показниками психологічного благополуччя, позитивного і негативного афектів

\begin{tabular}{|l|c|c|}
\hline \multicolumn{1}{|c|}{ Показники } & IT «нарощуваного» інтелекту & IT «збагачуваної» особистості \\
\hline Позитивні відношення & $\mathbf{0 , 2 3 1 *}$ & $\mathbf{0 , 3 1 1 ^ { * * }}$ \\
\hline Автономія & 0,136 & $\mathbf{0 , 2 3 8 ^ { * }}$ \\
\hline Керування середовищем & 0,127 & 0,133 \\
\hline Особистісне зростання & 0,074 & 0,051 \\
\hline Цілі в житті & $\mathbf{0 , 2 2 3 *}$ & 0,136 \\
\hline Самоприйняття & $\mathbf{0 , 2 3 1 *}$ & $\mathbf{0 , 2 4 5 *}$ \\
\hline Психологічне благополуччя & 0,194 & $\mathbf{0 , 2 2 1 *}$ \\
\hline Позитивний афект & 0,215 & 0,191 \\
\hline Негативний афект & $-0,160$ & $-0,124$ \\
\hline
\end{tabular}

Примітка. * - статистично значущі зв'язки на рівні $\mathrm{p} \leq 0,05$ ** - статистично значущі зв'язки на рівні $\mathrm{p} \leq 0,01$ 
Регресійна статистика для однофакторної моделі адаптивності особистості

\begin{tabular}{|l|c|}
\hline \multicolumn{1}{|c|}{ Показники } & Розраховане значення \\
\hline Множинний R & 0,376 \\
\hline R-квадрат & 0,141 \\
\hline Нормований R-квадрат & 0,130 \\
\hline Стандартна похибка & 5,255 \\
\hline
\end{tabular}

Таблиця 6

Характеристика кореляційно-регресійних зв’язків між фактором та результативним показником для однофакторної моделі адаптивності особистості

\begin{tabular}{|l|c|c|c|}
\hline \multicolumn{1}{|c|}{ Показники } & Коефіціенти регресії & t-критерій Стьюдента & Р-значення \\
\hline $\begin{array}{l}\text { Прийняття теорії «нарощуваного» } \\
\text { інтелекту }\end{array}$ & 0,376 & 3,584 & 0,001 \\
\hline
\end{tabular}

Розрахована регресійна модель є значущою за критерієм F-Фішера ( $\mathrm{F}=12,843, \mathrm{p}=0,001)$.

Отже, за результатами регресійного аналізу з'являеться можливість прогнозування рівня вираженості адаптаційного потенціалу особистості на основі показників її імпліцитних теорій.

Висновки і пропозиції. За результатами теоретичного аналізу та емпіричного дослідження встановлено, що такі особистісні конструкти як імпліцитні теорії виступають в якості важливих фракторів (предикторів) забезпечення психічної саморегуляції та адаптаційного потенціалу особистості. Психологічна робота, спрямована на зміну імпліцитних компонентів самосвідомості особистості, може стати едрективним ресурсом підвищення адаптаційного потенціалу людини. Сприяння розвитку самосвідомості, суб'єктної активності, фрормування інкрементальних імпліцитних уявлень про власну особистість та інтелект може знизити ризик дезадаптивних проявів у життедіяльності людини та значно підвищити ії̈ суб’ективне благополуччя.

\section{Список літератури:}

1. Березин Ф.Б. Психологическая и психофизическая адаптация человека. Ленинград : Наука, 1988.260 с.

2. Галузо П.Р. Базовые смысловые установки и осознанная регуляция учебной деятельности студентов. Актуальные проблемы психологии личности : сборник научных статей. 2016. С. 201-214.

3. Захарова Н.С. Субъектно-личностные аспекты адаптации одаренных студентов к обучению в высшей школе. The Emissia. Offline Letters. 2013. URL: http://www.emissia.org/offline/2013/1991.htm (дата звернення: 20.12.2020).

4. Леонтьев Д.А. Саморегуляция, ресурсы и личностный потенциал как потенциал саморегуляции. Сибирский психологический журнал. 2016. № 4(62). С. 18-37.

5. Маклаков А.Г. Личностный адаптационный потенциал: его мобилизация и прогнозирование в экстремальных условиях. Психологический журнал. 2001. № 1. С. 16-24.

6. Посохова С.Т. Психология адаптирующейся личности. Санкт-Петербург : Изд-во РГПУ им. Герцена, 2001.240 с.

7. Санникова О.П., Кузнецова О.В. Комплексная диагностика адаптивности личности. Science and Education a New Dimension. Pedagogy and Psychology. 2017. V (53). C. 84-89.

8. Bruner J.S., Tagiuri R. The perception of people / Lindsay G. (Ed.): Handbook of social psychology. Cambridge : Addison-Wesley, 1954. Vol. 2. P. 634-654.

9. Dweck C.S. "Can Personality Be Changed? The Role of Beliefs in Personality and Change", Current directions In Psychological Science. 2008. Vol. 17. № 62. P. 391-394.

\section{References:}

1. Berezin F.B. (1988) Psihologicheskaya $i$ psihofizicheskaya adaptatsiya cheloveka [The psychological and psychophysical human adaptation]. Leningrad: Nauka. (in Russian)

2. Galuzo P.R. (2016) Bazovyie smyislovyie ustanovki i osoznannaya regulyatsiya uchebnoy deyatelnosti studentov [Basic semantic attitudes and conscious regulation of students' educational activity]. Aktualnyie problemyi psihologii lichnosti [Actual problems of personality psychology], pp. 201-214.

3. Zaharova N.S. (2013) Sub'ektno-lichnostnyie aspektyi adaptatsii odarennyih studentov k obucheniyu v vyisshey shkole [The subjective and personal aspects of the adaptation of gifted students to higher education]. The Emissia. Offline Letters (electronic journal). Available at: http://www.emissia.org/offline/2013/1991.htm (accessed 20.12.2020).

4. Leontiev D.A. (2016) Samoregulyatsiya, resursy i lichnostnyi potentsial [Self-regulation, resources and personality potential]. Sibirskii psikhologicheskii zhurnal [Siberian Psychological Journal], vol. 4(62), pp. 18-37.

5. Maklakov A.G. (2001) Lichnostnyi adaptacionnyi potencial: ego mobilizaciya i prognozirovanie v ekstremal'nyh usloviyah [Personal adaptive potential: its application and forecasting in extreme situations]. Psihologicheskii zhurnal, vol. 22, no. 1, pp. 16-24.

6. Posokhova S.T. (2001) Lichnostnaya regulyatsiya adaptatsii v izmenyayushcheysya sotsialnoy srede [Personal regulation of adaptation in changing social environment]. Psikhologicheskie problemy samorealizatsii lichnosti [Psychological problems of personal self-fulfillment]. St. Petersburg: St. Petersburg State University Press, pp. 111-121. (in Russian)

7. Sannikova O.P., Kuznietsova, O.V. (2017) Complex diagnosis of personality adaptability. Science and Education a New Dimension. Pedagogy and Psychology, V (53), issue 114, pp. 84-89.

8. Bruner J.S., Tagiuri R. (1954) The perception of people. Handbook of social psychology. Cambridge: AddisonWesley, vol. 2, pp. 634-654.

9. Dweck C.S. (2008) "Can Personality Be Changed? The Role of Beliefs in Personality and Change". Current directions In Psychological Science, vol. 17, no. 62, pp. 391-394. 